\title{
A MORALIDADE KANTIANA QUESTIONADA POR HEGEL: FUNDAMENTOS PARA A BIOÉTICA COMO FILOSOFIA MORAL
}

\author{
Ellara Valentini Wittckind* \\ Vanessa de Oliveira Bernardi** \\ Maria Eugenia Bunchaft***
}

SUMÁRIO: Introdução; 1.1 AMoralidade de Kant a partir do Imperativo Categórico; 1.2 Os Objetivos da Moralidade Kantiana; 1.3 A Liberdade enquanto Condição da Moralidade e a Responsabilidade como Tema de Filosofia; 2 Moralidade e Eticidade em Hegel e os Argumentos da Contradição e do Formalismo na Moral Kantiana; 2.1 Hegel e a Contradição e o Formalismo na Moral Kantiana; 2.2 Moralidade e Eticidade em Hegel; 3 A Bioética como Filosofia Moral fundamentada a partir das Filosofias Kantiana e Hegeliana; 4 Considerações finais; Referências.

RESUMO: Oobjetivo central deste artigoé proporcionar um debate entre a moralidade kantiana e a eticidade hegeliana, para se estabelecerem fundamentos à bioética como novo ramo da filosofia moral. A partir da análise do imperativo categórico kantiano, a teoria hegeliana mostra-se tanto contestatória quanto complementar à moralidade através da máxima do "dever pelo dever", estabelecendo sua eticidade via determinações do princípio da liberdade. O presente estudo decorre da análise das teorias de Kant e Hegel, através de referências bibliográficas próprias destes e em aportes de filósofos nacionais e estrangeiros, estudiosos destes clássicos autores. A partir disso, será demonstrado que é possível a existência de direitos morais universais, sem que se tenha de abandonar ou focar as ações humanas somente as (nas) intenções ou as (nas) consequências, mas pela união das mesmas, para se obter o fim maior que é a proteção da vida humana, em todas as suas formas, o que é defendido pela bioética.

PALAVRAS-CHAVE: Kant; Moral; Ética; Hegel; Bioética.

\section{KANTIAN MORALIT Y QUESTIONED BY HEGEL: BASIS OF BIOETHICS ASS MORAL PHILOSOPHY}

ABSTRACT: A debate between Kantian morality and Hegelian ethics is provided to establish the basis for Bioethics as a new branch of Moral Philosophy. Through

\footnotetext{
Advogada; Mestre pelo Programa de Pós-Graduação em Direito Público pela Universidade do Vale do Rio dos Sinos (UNISINOS) São Leopoldo (RS), Brasil. E-mail: ellarav@hotmail.com

** Advogada; Mestre pelo Programa de Pós-Graduação em Direito Público pela Universidade do Vale do Rio dos Sinos (UNISINOS) São Leopoldo (RS), Brasil

${ }^{* * * *}$ Docente do Programa de Pós-Graduação em Direito na Universidade do Vale do Rio dos Sinos (UNISINOS) São Leopoldo (RS), Brasil; Pós-Doutora em Filosofia pela Universidade Federal de Santa Catarina (UFSC), Brasil.
} 
the analysis of Kant's categorical imperative, Hegel's theory is contesting and complementary to morality by the motto 'duty for duty's sake'. Ethics are thus established through the freedom principle. Current study comprises Kant's and Hegel's theories through bibliographical references and based on Brazilian and foreign philosophers who studied these classical philosophers. The existence of universal moral rights is possible without quitting or focusing human actions merely on intentions or consequences but through the joining of both to obtain the greater end, or rather, the protection of human life in all its forms, defended by Bioethics.

KEY WORDS: Kant; Morality; Ethics; Hegel; Bioethics.

\section{LA MORALIDAD KANTIANA CUESTIONADA POR HEGEL: FUNDAMENTOS PARA LA BIOÉTICA COMO FILOSOFÍA MORAL}

RESUMEN: El objetivo central de este artículo es proporcionar un debate entre la moralidad kantiana y la ética hegeliana, a fin de establecerse fundamentos para la bioética como nueva rama de la filosofía moral. A partir del análisis del imperativo categórico kantiano, la teoría hegeliana se muestra tanto contestataria como complementar a la moralidad a través de la máxima del "deber por el deber", estableciendo su ética por medio de las determinaciones del principio de la libertad. El presente estudio sucede del análisis de las teorías de Kant y Hegel, a través de referencias bibliográficas propias de ellos y en aportes filosóficos nacionales y extranjeros, de estudiosos de estos autores clásicos. A partir de ello, será demostrado que es posible la existencia de derechos morales universales, sin que se tenga que abandonar o enfocar las acciones humanas solo las (en las) intenciones o las (en las) consecuencias, sino por la unión de estas, para obtenerse el fin más grande que es la protección de la vida humana, en todas sus formas, lo que es defendido por la bioética.

PALABRAS-CLAVE: Kant; Moral; Ética; Hegel; Bioética.

\section{INTRODUÇÃO}

A busca de um princípio último da moralidade é o fim da filosofia prática de Kant, o que se dá através do imperativo categórico, via metafísica. Kant parte da filosofia (conhecimento) moral comum para chegar a este princípio, o qual rejeita a ação humana balizada por inclinações. Assim, segundo o filósofo, o agir deve 
ser balizado pelo dever e não pelo interesse. Por outro lado, Hegel defende que o "dever pelo ser" é indefinido e abstrato, sendo necessária a abordagem da ética via reflexões acerca da liberdade e da responsabilidade humanas, porém não pelo enfoque dado por Kant. A partir desse fecundo debate, será possível estabelecer fundamentos para que a bioética seja considerada como um novo ramo da filosofia moral, sem sobrepor qualquer teoria (kantiana ou hegeliana), pois a consideração de suas nuances será peça chave para a presente análise.

Com base nisso, no primeiro item deste artigo será abordada a moralidade de Kant a partir do imperativo categórico, suas fórmulas e possibilidade, partindo para a análise da liberdade como condição da moralidade e da responsabilidade como tema de filosofia. No segundo item será abordada a crítica hegeliana à moralidade de Kant, pelos argumentos da contradição e do formalismo na moral kantiana, além da moralidade e da eticidade em Hegel. Por fim, no terceiro e último tópico será tratado a respeito da bioética como novo ramo da filosofia moral, baseada na moralidade e na eticidade kantiana e hegeliana.

Foram utilizadas obras de filósofos contemporâneos, a fim de se estabelecer a ponte entre as teorias de Kant e Hegel, haja vista que nas épocas nas quais estes viveram e publicaram seus estudos, não se tratava acerca de questões que hoje são temas de bioética, como eutanásia, eugenia via manipulação genética, fertilização artificial, aborto, transplantes de órgãos, questões LGBT, uso de medicina alternativa, de diversas tecnologias médicas e farmacológicas, etc.

Justifica-se o tema do presente artigo em razão de que o embate filosófico travado entre Kant e Hegel, a respeito da moralidade e da eticidade, possibilita a compreensão das mais diversas vertentes do direito e da própria filosofia, a partir do conhecimento a respeito das ações humanas. No presente artigo, as peculiaridades da moralidade kantiana e sua crítica, por parte de Hegel, serão abordadas para se estabelecer a influência das mesmas à bioética, como um novo ramo da filosofia moral.

\subsection{A MORALIDADE DE KANT A PARTIR DO IMPERATIVO CATEGÓRICO}

\subsubsection{Os Objetivos da Moralidade Kantiana}

Immanuel Kant desenvolveu seus estudos filosóficos a partir da investigação do universo espiritual humano, motivado pela fundamentação dos critérios 
universais e necessários para o conhecimento e para a ação humana. Kant procurou conciliar a perspectiva racionalista e a empirista na fundamentação da possibilidade do conhecimento e do agir humano, influenciado por Jean Jacques Rousseau e por David Hume.

A partir da publicação de Crítica da Razão Pura, a preocupação do filósofo passou das ciências naturais à filosofia da religião, à moral, à história e à ciência, e suas obras chegaram a delimitar os períodos pré e pós seu pensamento.

Assim, a preocupação da filosofia kantiana, quanto ao conhecimento e à ação humana, se consubstancia na justificação do pensamento puro, a priori, como fundamentação do conhecimento verdadeiro e da moralidade. Tudo isso, através de um pensamento crítico. O objetivo de Kant "não é buscar uma lei que indique algum conteúdo específico", mas sim "estabelecer um critério, mediante o qual se possam avaliar e julgar todos os conteúdos". 01

Nesse cenário, Kant se tornou um filósofo prestigiado devido à rejeição do conhecimento metafísico que explicaria a coisa em si (o noumenon), e a defesa do conhecimento puro, independente da experiência, mas constituído a partir de um sujeito que experiencia e emite juízos sintéticos a priori sobre ele (o conhecimento puro). A partir disso, para o filósofo, é possível ao sujeito emitir juízos necessários e universais, sendo, somente estes, efetivamente conhecimento puro.

$\mathrm{O}$ ato de conhecer, então, limita-se pela intuição sensível, mesmo que ela se dê a priori. Portanto, a metafísica não pode ser tida como conhecimento científico, como a matemática, da estatística e da física. Nesse passo, a metafísica só seria possível como estudo das formas a priori da razão, e não para conhecer o que estaria fora dela, como o mundo e o espírito, por exemplo. ${ }^{02}$

A Fundamentação da Metafísica dos Costumes foi o primeiro livro no qual Kant voltou sua atenção para a moralidade humana. Nela, o filósofo procurou identificar o juízo sintético a priori universal (o princípio supremo da moralidade) ${ }^{03}$ ao qual toda ação humana deve se submeter: o imperativo categórico, "o que constitui, só por si, no seu propósito, uma tarefa completa e bem distinta de qualquer outra investigação moral”. ${ }^{4}$

\footnotetext{
${ }^{01}$ WEBER, Thadeu. Ética e Filosofia Política: Hegel e o formalismo kantiano. Porto Alegre: EDIPUCRS, 1999, p. 52.

${ }^{02}$ MONDIN, Battista. Curso de Filosofia. Tradução: Benoni Lemos. Vol. II. 3 vols. São Paulo, SP: Paullus, 2007, p. 215.

${ }_{03} 10$ Segundo Kant: "A presente fundamentação nada mais é, porém, do que a busca e fixação do princípio supremo da moralidade (...), tarefa completa em seu propósito, devendo separar-se de qualquer investigação moral." KANT, Fundamentação da Metafísica dos Costumes e Outros Escritos, Tradução: Leopoldo Holzbach. São Paulo, SP: Martin Claret, 2005, Prólogo, p. 18.

${ }^{04}$ KANT, Immanuel. Grundlegung zur Metaphysik der Sitten. Tradução de Paulo Quintela, Lisboa: Edições 70, 1986, XV.
} 
Em Crítica da Razão Prática foi estabelecido o conhecimento possível, dando-lhe fundamento para que pudesse responder às questões decorrentes das ações humanas através da crítica da razão voltada para o dever e para a moral. Por isso, defendeu o filósofo, que "não temos que determinar os princípios do que acontece, mas sim as leis do que deve acontecer (was gescheben soll), mesmo que nunca aconteça, quer dizer, leis objetivo-práticas". ${ }^{5}$ Com isso, a razão é sempre universal, seja ela pura (teórica) ou prática; é a mesma para todos, podendo variar seus conteúdos no espaço e no tempo, mas não sua forma enquanto atividade racional. ${ }^{06}$

A pureza da razão e sua praticidade possibilitam que se possa determinar a priori a universalidade e a necessidade das ações e o modo pelo qual a vontade poderá ser exteriorizada através de ações conformes ao contingente e ao particular, a partir dos motivos empíricos para sua consecução. Com isso, mesmo se a ação não for tomada por dever, será, na prática, exercida conforme o dever, haja vista que seu fundamento decorre de um princípio apriorístico. É aí que se estabelece a "metafísica dos costumes", pois se assenta no conhecimento calcado a partir da razão prática que age de acordo com princípios prévios à experiência. A razão pura prática difere o ser humano dos demais animais, pois ela possibilita que as ações dos indivíduos se guiem pela necessidade e universalidade e não pela contingência e particularidade das mesmas. ${ }^{07}$

É a partir da conformação do princípio objetivo com a subjetividade humana que se constitui a vontade. Essa conformação é o mandamento, chamado por Kant de "imperativo", o qual determina uma ação com fim nela mesma. O imperativo categórico não se refere a qualquer propósito a posteriori, valendo como princípio apodítico prático, uma vez que declara a ação boa em si, passível de ser universalizada. $^{08}$

Esse imperativo foi denominado de moralidade, sendo considerado "Lei Suprema Universal". O primeiro imperativo categórico de moralidade ao qual Kant se refere é "age só segundo a máxima tal que possas ao mesmo tempo querer que ela

\footnotetext{
${ }^{05}$ KANT, Immanuel. Grundlegung zur Metaphysik der Sitten. Tradução de Paulo Quintela, Lisboa: Edições 70, 1986, p. 62.

${ }^{06}$ CHAUÍ, Marilena de Souza. Convite à Filosofia. São Paulo, SP: Ática, 2000, p. 170.

${ }^{07}$ KANT, Immanuel. Grundlegung zur Metaphysik der Sitten. Tradução de Paulo Quintela, Lisboa: Edições 70, 1986.

${ }^{08}$ KANT, Immanuel. Grundlegung zur Metaphysik der Sitten. Tradução de Paulo Quintela, Lisboa: Edições 70, 1986.
} 
se torne universal". ${ }^{09}$ Sendo assim, a partir do imperativo categórico, toda ação que se deseja ser uma lei válida para todos os seres humanos é uma ação moral.

Com isso, pode-se sintetizar que o imperativo categórico não determina que, por exemplo, não se deve matar. Ele impõe que se questione: pode-se querer que a máxima que leva a tirar a vida de outrem possa ser tomada como lei universal? Daí surge a ideia de reciprocidade, no sentido de que a universalidade da lei moral implica que haja obrigações entre as pessoas. ${ }^{10}$

Dessa forma, Kant determina que o imperativo prático (a fórmula da lei do homem como um fim em si mesmo): "age de tal maneira que passas a usar a humanidade, tanto em tua pessoa como na pessoa de qualquer outro, sempre e simultaneamente como fim e nunca simplesmente como meio". ${ }^{11}$

A segunda fórmula do imperativo categórico é a da lei da natureza, enunciada assim: "age como se a máxima de tua ação se devesse tornar, pela tua vontade, lei universal da natureza". Segundo esse princípio, "temos que poder querer que uma máxima da nossa ação se transforme em lei universal". ${ }^{12}$

Kant conclui que "não temos que determinar os princípios do que acontece, mas sim as leis do que deve acontecer, mesmo que nunca aconteça, quer dizer leis objetivo-práticas". ${ }^{13}$ Esse princípio, portanto, deve estar livre de todas as influências da experiência e, assim, nos dirá o que é, mas não o que deve ser. Comenta Paton que, pela máxima em questão, "colocamo-nos de forma imaginária na posição do Criador e supomos que estamos construindo um mundo da natureza do qual nós mesmos somos parte". ${ }^{14}$

A terceira fórmula do imperativo categórico da moralidade diz: "age de tal maneira que uses a humanidade, tanto na tua pessoa como na pessoa de qualquer outro, sempre e simultaneamente, como fim e nunca simplesmente como meio". ${ }^{15}$ Tratar o outro como meio, segundo Kant, significa manipulá-lo, não possibilitar que

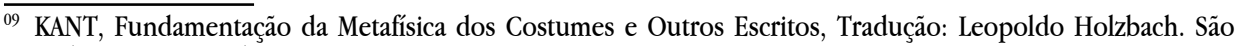
Paulo, SP: Martin Claret, 2005, Primeira Seção, p. 51.

${ }^{10}$ WEBER, Thadeu. Ética e Filosofia Política: Hegel e o formalismo kantiano. Porto Alegre: EDIPUCRS, 1999.

${ }^{11}$ KANT, Fundamentação da Metafísica dos Costumes e Outros Escritos, Tradução: Leopoldo Holzbach. São Paulo, SP: Martin Claret, 2005, Primeira Seção, p. 59.

${ }^{12}$ KANT, Immanuel. Grundlegung zur Metaphysik der Sitten. Tradução de Paulo Quintela, Lisboa: Edições 70, 1986, p. 52.

${ }^{13}$ KANT, Immanuel. Grundlegung zur Metaphysik der Sitten. Tradução de Paulo Quintela, Lisboa: Edições 70, 1986, p. 62.

${ }^{14}$ PATON, H. J. The categorial imperative - a study in Kant's moral philosophy. Philadelphia: University of Pennsylvania Press, 1071, p. 146.

${ }^{15}$ KANT, Immanuel. Grundlegung zur Metaphysik der Sitten. Tradução de Paulo Quintela, Lisboa: Edições 70, 1986, p. 67. 
ele consinta comigo. Assim, não o respeito como ser humano que é. Assim agindo, não pratico ato moral, pois não posso universalizar o desrespeito. Do mesmo modo, não se vislumbra ato moral utilizar o outro simplesmente como meio, para concretizar fins individuais, ou para satisfazer a inclinações.

A quarta fórmula é a da autonomia da vontade, segundo a qual Kant propõe: "age de tal maneira que a vontade pela sua máxima se possa considerar a si mesma, ao mesmo tempo, como legisladora universal". ${ }^{16}$ Nessa máxima, o filósofo defende que a vontade livre é aquela que obedece à lei da qual é autora, tratando-se de uma submissão a si mesmo. Weber esclarece que, para esta fórmula, "somos autores da lei a que obedecemos. Estamos sujeitos à lei, tão-somente porque somos considerados os autores da lei. Isso é vontade livre ou autonomia". ${ }^{17}$ Paton acrescenta que "se existe um imperativo categórico, a vontade moral que lhe obedece não deve ser determinada por interesse, e por isso deve ela mesma produzir a lei universal à qual está incondicionalmente obrigada a obedecer". ${ }^{18}$

Por último, a fórmula do reino dos fins decorre da quarta formulação, sendo explicada como a necessidade de que o ser humano aja sempre como se fosse membro legislador de um reino universal de fins. Este reino, segundo Kant, trata-se da "ligação sistemática de vários seres racionais por meio de leis comuns". ${ }^{19}$ Aqui, volta à tona a noção de dignidade e de que o outro não pode ser tratado como meio, mas como fim em si mesmo. Do mesmo modo, há a necessidade de que cada um se reconheça como fim e reconheça os demais, do mesmo modo, retornando, também, o conceito de reciprocidade.

Segundo afirma Weber, o reino dos fins se refere aos fins individuais desde que não entrem em conflito com a lei universal. $\mathrm{O}$ fato de um indivíduo agir como membro legislador deste reino, possibilita que haja coerência entre os seres racionais. A formulação do reino dos fins representa, em Kant, a união da forma e da matéria da ação moral, no que se vislumbra a íntima ligação entre pessoa, dignidade e respeito. ${ }^{20}$

\footnotetext{
${ }^{16}$ KANT, Immanuel. Grundlegung zur Metaphysik der Sitten. Tradução de Paulo Quintela, Lisboa: Edições 70, 1986, p. 76.

${ }^{17}$ WEBER, Thadeu. Ética e Filosofia Política: Hegel e o formalismo kantiano. Porto Alegre: EDIPUCRS, 1999, p. 42.

${ }^{18}$ PATON, H. J. The categorial imperative - a study in Kant's moral philosophy. Philadelphia: University of Pennsylvania Press, 1071, p. 182.

${ }^{19}$ KANT, Immanuel. Grundlegung zur Metaphysik der Sitten. Tradução de Paulo Quintela, Lisboa: Edições 70, 1986, p. 74 .

${ }^{20}$ WEBER, Thadeu. Ética e Filosofia Política: Hegel e o formalismo kantiano. Porto Alegre: EDIPUCRS, 1999, p. $44-45$.
} 
Paton sintetiza que o reino dos fins é:

[...] uma comunidade de pessoas racionais, obedecendo à mesma lei moral por sua própria causa (conta), respeitando cada um a liberdade do outro e, neste sentido, empenhando-se em realizar um sistema harmonioso de fins tais que não podem ser realizados por outro viés (em outro sentido). O dever de um homem bom é agir como membro legislador de uma comunidade ideal. ${ }^{21}$

Considerando as formulações do imperativo categórico, especialmente a do reino dos fins, deve-se questionar de que modo o imperativo categórico se torna possível? Kant refere que:

Para lá dos objetos da experiência, portanto, relativamente às coisas enquanto númenos, todo o positivo de um conhecimento era recusado com pleno direito à razão especulativa. Esta, no entanto, conseguiu salvaguardar o conceito dos númenos, isto é, a possibilidade, e até a necessidade, de os pensar. ${ }^{22}$

Caffarena estabelece que a lei moral se apresenta como uma ligação entre o noumenon (atemporal) e os fenômenos (temporais) de ação prática, considerando a identidade entre aquela e a consciência de liberdade.$^{23}$ É isto que possibilita que a lei moral atue sobre o mundo sensível, ou seja, mesmo que não seja possível conhecer a liberdade, é possível pensá-la (mundo inteligível).

É na ideia de liberdade que se pauta a possibilidade do imperativo categórico. Nesse sentido, Kant demonstra que o ser humano habita dois mundos, o inteligível - onde se submete às leis da razão, e o sensível, no qual se guia por inclinações. O filósofo defende que o inteligível é "imediatamente legislador" ${ }^{24} \mathrm{da}$ vontade humana. Isto se justifica porque este é o fundamento do mundo sensível. A partir daí, o indivíduo deve-se guiar pela razão, submetendo-se à lei do mundo inteligível, que nada mais é que o imperativo categórico. Assim o fazendo, poderá ser livre e estará agindo autonomamente.

A par disso, o próximo tópico tratará de outros detalhes a respeito da

\footnotetext{
${ }^{21}$ PATON, H. J. The categorial imperative - a study in Kant's moral philosophy. Philadelphia: University of Pennsylvania Press, 1071, p. 190.

${ }^{22}$ Immanuel. Kritik der reinen Vernunft - Crítica da Razão Pura. Tradução de M. P. dos Santos e A. F. Morujão. Lisboa: Fundação Calouste Gulbenkian, 1994, p. 73.

${ }^{23}$ CAFFARENA, E. Gomez. Razón Práctica, Razón Utópica. In Agora Papelos de Filosofía. Santiago de Compostela: Inprensa Universitaria, 1988, p. 177-192, p. 180.

${ }^{24}$ KANT, Immanuel. Grundlegung zur Metaphysik der Sitten. Tradução de Paulo Quintela, Lisboa: Edições 70, 1986, p. 111.
} 
liberdade enquanto condição da moralidade e a responsabilidade como tema da filosofia kantiana, fechando a abordagem de suas teorias, nos limites propostos pelo presente ensaio.

\subsection{A LIBERDADE ENQUANTO CONDIÇÃO DA MORALIDADE E RESPONSABILIDADE COMO TEMA DE FILOSOFIA}

Como referido, a liberdade é o pressuposto básico para a possibilidade do imperativo categórico. Todos os seres racionais devem possuir liberdade e todos devem reconhecê-la nos outros. Em sua Crítica da Razão Prática, Kant defende que "é preciso que uma vontade livre, independente da máxima de lei, encontre, não obstante, na lei um princípio de determinação". ${ }^{25}$ Disso se conclui que quando as ações não são determinadas por causas externas, são livres. São livres das influências e estão agindo de acordo com a mais pura razão.

A liberdade como independência de toda matéria é a face negativa da liberdade em Kant. Assim, dizer que as vontades dos agentes são livres significa que elas não são determinadas por causas externas,$^{26}$ que o ser humano está livre da influência dos sentidos, que é determinado por pura razão. ${ }^{27} \mathrm{~A}$ liberdade em sentido prático, portanto, é "a independência do arbítrio frente à coerção pelos impulsos da sensibilidade". ${ }^{28}$

A partir dessa concepção surge a liberdade como autonomia da vontade, a qual se caracteriza por ser a "determinação do livre arbítrio pela simples forma legisladora universal". ${ }^{29}$ Barretto descreve o elemento da liberdade como autonomia sendo "a propriedade da vontade graças à qual esta é para si mesma a sua lei, somente sendo livre aquele capaz de tornar-se, por meio da vontade própria, fonte das suas próprias leis, ou seja, autônomo". ${ }^{30}$

Com isso, pode-se arguir que somente a vontade autônoma, independente

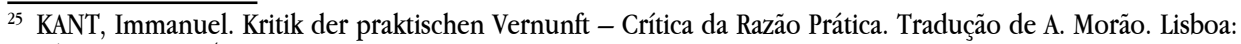
Edições 70, 1994, p. 52.

${ }^{26}$ PATON, H. J. The categorial imperative - a study in Kant's moral philosophy. Philadelphia: University of Pennsylvania Press, 1071, p. 210.

${ }^{27}$ TUGENDHAT, Ernst. Lições sobre ética. Tradução de Ernildo Stein e Ronai Rocha. Petrópolis: Vozes, 1997, p. 70.

${ }^{28}$ KANT, Immanuel. Kritik der reinen Vernunft - Crítica da Razão Pura. Tradução de M. P. dos Santos e A. F. Morujão. Lisboa: Fundação Calouste Gulbenkian, 1994, p. 562.

${ }^{29}$ KANT, Immanuel. Kritik der praktischen Vernunft - Crítica da Razão Prática. Tradução de A. Morão. Lisboa: Edições 70, 1994, p. 68.

${ }^{30}$ BARRETTO, Vicente de Paulo; BRAGATO, Fernanda Frizzo. Leituras de Filosofia do Direito. Curitiba: Juruá, 2013, p. 204. 
de toda matéria de lei pode conferir a si própria um princípio válido a todos. A liberdade da vontade é autonomia, isto é, a liberdade é a "propriedade da vontade de ser lei para si mesma". ${ }^{31}$

Ocorre que se a vontade é o poder do agente de agir conforme as leis que ele dá a si mesmo, não é possível a existência de uma vontade livre que não se submeta às leis. Assim, de que forma a lei poderá determinar a vontade? A resposta de Kant é a seguinte:

[...] o modo como uma lei pode por si e imediatamente ser princípio determinante de vontade (o que, no entanto, é o essencial de toda moralidade) constitui um problema insolúvel para a razão humana e confunde-se com o problema de como é possível uma vontade livre. ${ }^{32}$

Kant se preocupa em demonstrar como uma vontade pode ser livre, e não provar que ela o é. Volta-se ao questionamento anterior: pode uma vontade livre escolher agir contra a lei? O filósofo defende que somos livres para agirmos de acordo com a lei moral. Não há liberdade para agir contra a lei. ${ }^{33}$ Isto porque, o "homem bom visa às consequências por causa da lei: ele não obedece à lei simplesmente por causa das consequências". ${ }^{34}$

Com isso, tem-se que Kant defende que só é possível expor a ideia de liberdade via reflexão sobre a lei moral e a lei moral só é possível pela ideia de liberdade. ${ }^{35}$ Conforme Roani ${ }^{36}$, "é a própria consciência que testemunha a favor do princípio moral, pois é ela própria que afirma a legitimidade do dever moral”. Acrescenta o estudioso que "a partir do imperativo categórico pode-se saber o que se deve fazer para que o querer seja moralmente bom".

A liberdade, porém, se reflete na responsabilidade, a qual, segundo a teoria kantiana, "suscita a indagação a respeito da unidade da pessoa e sua identidade pessoal, procurando determinar os limites da autonomia racional e como se situa a questão da alteridade" ${ }^{37}$ Acrescenta Barretto que a "ideia de responsabilidade

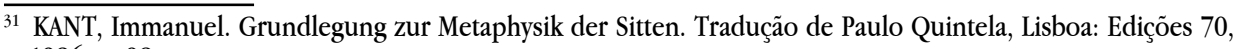
1986, p. 98.

32 KANT, Immanuel. Kritik der praktischen Vernunft - Crítica da Razão Prática. Tradução de A. Morão. Lisboa: Edições 70, 1994, p. 128.

${ }^{33}$ WEBER, Thadeu. Ética e Filosofia Política: Hegel e o formalismo kantiano. Porto Alegre: EDIPUCRS, 1999.

${ }^{34}$ PATON, H. J. The categorial imperative - a study in Kant's moral philosophy. Philadelphia: University of Pennsylvania Press, 1071, p. 76.

35 KANT, Immanuel. Kritik der praktischen Vernunft - Crítica da Razão Prática. Tradução de A. Morão. Lisboa: Edições 70, 1994.

${ }^{36}$ ROANI, Alcione Roberto. Moral e Direito - Kant versus Hegel. Passo Fundo; IFIPE, 2006, p. 43.

${ }^{37}$ BARRETTO, Vicente de Paulo; BRAGATO, Fernanda Frizzo. Leituras de Filosofia do Direito. Curitiba: Juruá, 2013, p. 275. 
justifica-se como a espinha dorsal da vida social em virtude da qual os homens concebem-se uns aos outros como agentes morais". ${ }^{38}$

Para Kant, a responsabilidade se caracteriza como a ação da razão prática, sendo dependente da liberdade. Conforme interpretem Meneses e Reis, a "noção de responsabilidade é apoiada na noção de livre escolha. Em princípio, se o ser humano é livre, então cabe a ele assumir as consequências dos seus actos" ${ }^{\prime 39}$, ressaltando também que:

A liberdade de escolha é condição de possibilidade para que a pessoa seja responsável pela sua acção. Cabe a cada um responder, diante de si mesmo e diante dos outros, pelo que faz ou pelo que deveria fazer e não fez. Nesse sentido, a responsabilidade exige fundamentalmente a consciência dos actos praticados, a capacidade de sentido adequado aos princípios éticos.

Como sintetiza Barretto, o que Kant pretende "é estabelecer se é possível a atribuição de responsabilidade a alguém através de critérios morais definidos pela razão".$^{40}$ Com isso, expõe o mesmo autor que a "imputação moral faz a pessoa responsável por um ato bom ou mau, na medida em que seja a causa livre de sua manifestação", concluindo que a "responsabilidade moral remete, portanto, à constatação da livre subjetividade do agente". ${ }^{41}$

Assim, para a filosofia kantiana, a ação é moralmente correta quando o que a determina o é. Assim, as consequências da ação não lhe importam e, como referem Meneses e Reis, a "ética de Kant é uma ética da 'boa vontade". ${ }^{42}$ Podemos sintetizar, então, que "o que se impõe com força normativa à consciência moral é a realização do bem. Deduzir o dever do ser significa que é necessário encontrar um fundamento teórico para a obrigação moral". 43

Kant entende que a regra prática decorre da razão, a qual preserve a ação

\footnotetext{
$\overline{{ }^{38} \text { BARRETTO, Vicente }}$ de Paulo; BRAGATO, Fernanda Frizzo. Leituras de Filosofia do Direito. Curitiba: Juruá, 2013, p. 275.

${ }^{39}$ MENESES, Ramiro Délio Borges de; REIS, Ana M. Machado Gonçalves Reis. Responsabilidade em Kant e em Lévinas: entre os conceitos e os fundamentos. In Ágora Filosófica. Ano 9, n. 2, jul./dez./2009, p. 103-126. Disponível em < http://www.saavedrafajardo.org/Archivos/59.pdf > . Acesso em 07, ago./2015, p. 111.

${ }^{40}$ BARRETTO, Vicente de Paulo; BRAGATO, Fernanda Frizzo. Leituras de Filosofia do Direito. Curitiba: Juruá, 2013, p. 275.

${ }^{41}$ BARRETTO, Vicente de Paulo; BRAGATO, Fernanda Frizzo. Leituras de Filosofia do Direito. Curitiba: Juruá, 2013, p. 276.

${ }^{42}$ MENESES, Ramiro Délio Borges de; REIS, Ana M. Machado Gonçalves Reis. Responsabilidade em Kant e em Lévinas: entre os conceitos e os fundamentos. In Ágora Filosófica. Ano 9, n. 2, jul./dez./2009, p. 103-126. Disponível em < http://www.saavedrafajardo.org/Archivos/59.pdf>. Acesso em 07, ago./2015, p. 107.

${ }_{43}$ MENESES, Ramiro Délio Borges de; REIS, Ana M. Machado Gonçalves Reis. Responsabilidade em Kant e em Lévinas: entre os conceitos e os fundamentos. In Ágora Filosófica. Ano 9, n. 2, jul./dez./2009, p. 103-126. Disponível em < http://www.saavedrafajardo.org/Archivos/59.pdf>. Acesso em 07, ago./2015, p. 110.
} 
como meio para o efeito, como intenção, ou seja: "o que unicamente interessa aqui é a determinação da vontade o princípio determinante da máxima desta, enquanto vontade livre, e não o resultado". ${ }^{44}$ Como simplifica Weber ${ }^{45}$, o intuito de Kant é ocupar-se com o estabelecimento do modo como a razão determina a vontade. $\mathrm{O}$ desdobramento disso, ou seja, os resultados e as consequências, não são objeto de seus questionamentos. Em suma, os resultados e as consequências das ações não podem, para a teoria kantiana, ser os fundamentos que determinam as ações pretensiosas a terem valor moral.

Sob esse prisma, o debate entre Kant e Hegel demonstra que os dois filósofos trilharam caminhos diferentes, mas que se complementam. Enquanto Kant pretende estabelecer o princípio supremo da moralidade, através de seu aspecto formal, Hegel preocupa-se com a concretização da ideia de liberdade nas instituições sociais, demonstrando-se preocupado com as repercussões das ações humanas.

$\mathrm{O}$ primeiro estuda a intenção dos agentes e o segundo, os resultados e consequências das ações humanas. O que se pretende, no próximo ponto, é demonstrar a complementaridade entre as teses de Kant e Hegel quanto aos atos humanos, através da crítica deste ao formalismo da moralidade kantiana.

\section{MORALIDADE E ETICIFADE EM HEGEL E OS ARGUMENTOS DA CONTRADIÇÃO E DO FORMALISMO NA MORAL KANTIANA}

Georg Wilhelm Friedrich Hegel foi um filósofo alemão que baseou seus estudos na ideia de que as contradições e dialéticas são resolvidas para a criação de um modelo, que tanto pode refletir-se no espírito - sentido de alma e aspirações ideais -, como no Estado político.

Hegel defendeu que o critério de moralidade de Kant (poder querer que uma máxima de nossa ação se converta em lei universal) é formalmente vazio, além de ambíguo e insuficiente. Ele defende, segundo Weber, que "a possibilidade de dar-se a si próprio a lei implica a mediação das vontades dos outros; busca-se o universal, através da mediação" ${ }^{46}$

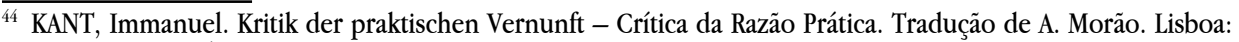
Edições 70, 1994, A, 79.

45 WEBER, Thadeu. Ética e Filosofia Política: Hegel e o formalismo kantiano. Porto Alegre: EDIPUCRS, 1999.

${ }^{46}$ WEBER, Thadeu. Ética e Filosofia Política: Hegel e o formalismo kantiano. Porto Alegre: EDIPUCRS, 1999, p. 75.
} 
O que Hegel chama de "vazio formalismo" ${ }^{47}$ na moralidade de Kant é a separação indevida entre forma e matéria. Entende Hegel que não há condição de se fixar o princípio supremo da moralidade somente através da parte formal de uma ação. Assim o filósofo escreve:

A essência da vontade pura e da razão pura prática consiste em que se abstraia todo conteúdo, resultando então contraditório em si [mesmo] buscar uma legislação ética, pois, dado que teria que ter um conteúdo, segundo a razão prática absoluta, sua essência consiste em não ter conteúdo. ${ }^{48}$

O que defende Hegel, em oposição a Kant, é que o princípio ético resulta da determinação e mediação das vontades livres dos agentes, além de constituir-se em história e tempo, implicando forma e conteúdo, este também universalizável. A lei resultante dessa conjectura vale para uma comunidade ética, respeitados seus costumes, origens e cultura, e pode, com isso, não valer para todos os seres racionais. Assim, através da aplicação da teoria hegeliana não se cairia num relativismo moral se no desdobramento da história a coerência universal das vontades livres for mantida.

A partir dessas primeiras linhas, tratando a respeito das diferenças basilares entre as teorias de Kant e Hegel, passa-se à abordagem do problema da contradição e do formalismo na moralidade kantiana, para, após, estabelecer as bases da moralidade e da eticidade hegelianas.

\subsection{HEGEL E A CONTRADIÇÃO E O FORMALISMO NA MORAL KANTIANA}

Kant baseou sua filosofia moral na não contradição entre uma máxima e a lei universal. Ou seja, a não contradição representa o fato de que uma máxima deve poder ser convertida em lei universal, que valha para todos. Se, entretanto, o indivíduo quiser algo para si e não para os outros, ou abrir uma exceção em seu favor, cairá em contradição. ${ }^{49}$ Esse critério, para Kant, serve para determinar se a conduta do indivíduo é ou não moral.

Hegel, ao revés, suscita que a ausência de contradição é uma "indeterminação

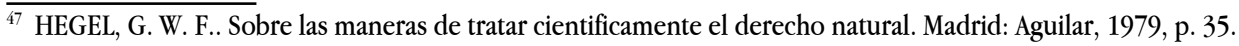

${ }^{48}$ HEGEL, G. W. F.. Sobre las maneras de tratar cientificamente el derecho natural. Madrid: Aguilar, 1979, p. 35.

${ }^{49}$ WEBER, Thadeu. Ética e Filosofia Política: Hegel e o formalismo kantiano. Porto Alegre: EDIPUCRS, 1999, p. 79 , nota 23 .
} 
abstrata", significa apenas "uma concordância formal consigo mesmo".${ }^{50} \mathrm{O}$ problema, para Hegel, é que a moralidade kantiana, através do imperativo categórico, não estabelece o que deve ser feito. Então, não haverá contradição onde nada é determinado. Além disso, esse cenário representa a possibilidade de a vontade acabar por "cair no mal"

A determinação do dever como ausência de contradição, a formal concordância consigo, que não é outra coisa que o estabelecimento da indeterminação abstrata, não se pode passar à determinação de deveres particulares, nem quando um conteúdo particular se apresenta na ordenação da ação existe nesse princípio um critério para se saber se é um dever ou não. Pelo contrário, todas as modalidades de ações injustas ou imorais podem justificar-se dessa maneira. ${ }^{52}$

Deste modo, preocupa-se a teoria hegeliana com o fato de que se o imperativo não enuncia o que deve ser feito, poderá a ação culminar num ato injusto e imoral, justificando-se através daquele. Hegel defende a dialética como o "princípio motor do conceito, que dissolve, mas também produz as particularidades do universal" ${ }^{53}$

Hegel argumenta que Kant propõe tautologias, pois, por exemplo, se há propriedade, deve haver propriedade. Se não há propriedade, então não deve haver propriedade. Conclui que "de acordo com a verdade, a sublime aptidão da autonomia da legislação da razão prática pura consiste na produção de tautologias" ${ }^{54}$

Uma contradição só pode surgir com algo que é, com um conteúdo que subjaz previamente como princípio firme. Só com referência a um princípio semelhante uma ação é concordante ou contraditaria.

O que Hegel leciona é a determinação do dever não pode se dar somente através da ausência de contradição, pois se nada é determinado, como poderão ser determinadas as vontades particulares? Na ótica hegeliana, este critério é insuficiente para distinguir o bem do mal, pois deposita na consciência "o poder judicatório de por si mesma determinar, quanto a um conteúdo, se é bom". ${ }^{5}$.

Para Hegel, a tese kantiana da contradição só funciona se o conteúdo moral já for conhecido pela comum razão humana, não sendo o imperativo categórico

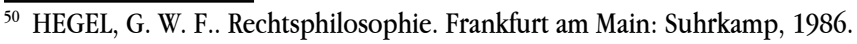

${ }^{51}$ HEGEL, G. W. F.. Rechtsphilosophie. Frankfurt am Main: Suhrkamp, 1986, § 139.

${ }^{52}$ HEGEL, G. W. F.. Rechtsphilosophie. Frankfurt am Main: Suhrkamp, 1986, § 135, nota.

${ }^{53}$ HEGEL, G. W. F.. Rechtsphilosophie. Frankfurt am Main: Suhrkamp, 1986.

${ }^{54}$ HEGEL, 1979, p. 34 e 167.

${ }^{55}$ HEGEL, G. W. F.. Rechtsphilosophie. Frankfurt am Main: Suhrkamp, 1986, § 138.
} 
um meio seguro para se tomar decisões sobre conteúdos particulares..$^{56} \mathrm{O}$ filósofo defende que as instituições e os costumes devem ser levados em conta quando se perquire a respeito da moralidade, e não considerá-las como algo externo, como Kant. Hegel pretende que sejam consideradas a fim de que os antagonismos provoquem a superação das contradições. ${ }^{57}$

A partir da ligação entre a moralidade e a eticidade, Hegel aponta as nuances de sua filosofia, em comparação com a kantiana, conforme será analisado em seguida.

\subsection{MORALIDADE E ETICIDADE EM HEGEL}

Como visto, Hegel defende que a vontade subjetiva se manifesta através da ação. A ação moral deve ser reconhecidamente minha; ter uma relação com o dever-ser (conceito) e referir-se à vontade dos demais. E acrescenta: "a convicção individual, e o saber a seu respeito, constituem um momento absoluto da moralidade.${ }^{58}$ Conclui Hegel que:

O conteúdo da vontade subjetiva ou moral [...] ainda que alcance a forma da objetividade, deve conservar sempre minha subjetividade; o acontecimento só tem validade, na medida em que está determinado interiormente por mim, na medida em que era meu propósito, minha finalidade. Na exteriorização não reconheço como meu nada mais do que estava na vontade subjetiva. ${ }^{59}$

O filósofo ressalta que o indivíduo não perde sua subjetividade quando realiza sua vontade, mas a conserva e a supera para reconhecer a subjetividade exterior, ou seja, a vontade do outro. Com isso, a realização dos fins de um indivíduo requer o reconhecimento da liberdade como princípio universal. É nesse momento que Hegel assevera que enquanto a moralidade se ocupa da subjetividade da vontade, a ética objetiva as determinações objetivas da vontade (culminando no encontro entre o conceito e o dever-ser da vontade). ${ }^{60}$

Kant escreve que o que unicamente interessa em seu estudo é a determinação da vontade e o princípio que a determina, enquanto vontade livre, independente

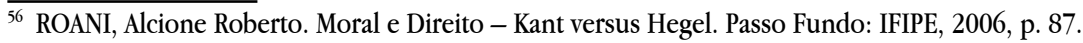

${ }^{57}$ ROANI, Alcione Roberto. Moral e Direito - Kant versus Hegel. Passo Fundo: IFIPE, 2006, p. 88.

${ }^{58}$ HEGEL, G. W. F.. Phänomenologie des Geistes. Frankfurt am Main: Suhrkamp, 1986, § 601, p. 103.

${ }^{59}$ HEGEL, G. W. F.. Rechtsphilosophie. Frankfurt am Main: Suhrkamp, 1986, §110.

${ }^{60}$ WEBER, Thadeu. Ética e Filosofia Política: Hegel e o formalismo kantiano. Porto Alegre: EDIPUCRS, 1999.
} 
do resultado. Weber sintetiza que a moral kantiana procurou estabelecer como a razão determina a vontade e não o que se desdobra dela. ${ }^{61}$ Já para Hegel, a regra prática decorre da mediação da vontade livre e desdobra-se no campo da eticidade, através das instituições sociais. Hegel preocupa-se com o que decorre do exercício das vontades livres. ${ }^{62}$

Barretto muito bem sintetiza o pensamento de Hegel da seguinte forma:

O indivíduo é pessoa no sentido puramente jurídico, situando-se no plano da universalidade abstrata. A moralidade, por sua vez, integra o estágio superior do pensamento da liberdade. O ponto de vista moral é o da liberdade subjetiva, no qual se enraíza o conhecimento do bem e do mal e do qual procede a ação moral. Esse ponto de vista implica a consciência do agir individual, a relação essencial ao conceito como um dever ser e a relação essencial com a vontade dos outros. Por fim, ocorre a passagem da moralidade para a eticidade e demarca-se a entrada no terreno concreto do exercício da vida ética ou da realidade efetiva da liberdade. A exposição dialética hegeliana coloca a interioridade do sujeito moral (moralidade) como mediação entre a objetivação do espírito no mundo das coisas (Direito abstrato) e sua objetivação no mundo histórico (eticidade). ${ }^{63}$

Assim, conforme enuncia Valcárcel, o papel da moralidade, para Hegel, é o de apresentar um sujeito que transcende da vontade subjetiva para a objetiva, ou seja, da moralidade para a eticidade, enquanto conceito de liberdade efetiva ${ }^{64}$

Hegel critica Kant em relação à defesa deste no sentido de que o ato imoral é o decorrente de exceções em favor do indivíduo. Isto porque, segundo a teoria hegeliana, existe o direito de emergência, o qual possibilita a defesa de um direito a partir de uma exceção, sem que isso seja considerado uma imoralidade. Exemplo dado pelo filósofo é o da pessoa que furta para não morrer de inanição. $\mathrm{O}$ direito à propriedade da coisa foi violado, porém, em nome de um direito fundamental: a vida.

Nessa senda, Hegel afirma, demonstrando a insuficiência do "direito abstrato":

\footnotetext{
${ }^{61}$ WEBER, Thadeu. Ética e Filosofia Política: Hegel e o formalismo kantiano. Porto Alegre: EDIPUCRS, 1999, p. 100 .

${ }^{62}$ WEBER, Thadeu. Ética e Filosofia Política: Hegel e o formalismo kantiano. Porto Alegre: EDIPUCRS, 1999, p. 100.

${ }^{63}$ BARRETTO, Vicente de Paulo; BRAGATO, Fernanda Frizzo. Leituras de Filosofia do Direito. Curitiba: Juruá, 2013, p. 81 .

${ }^{64}$ Amelia, Hegel y la ética. Sobre la superación de la "mera moral”, Barcelona: Editorial Anthropos, 1988, p. 350.
} 
O necessário é viver agora; o futuro não é absoluto e está entregue à contingência. Por isso, a necessidade do presente imediato pode justificar uma ação injusta, pois, com sua omissão, se cometeria, por sua vez, uma injustiça, e na verdade a maior injustiça, a total negação da existência da liberdade. ${ }^{65}$

Weber esclarece que Kant, ao enfatizar que o valor moral de uma ação está na intenção e no respeito à lei não significa que os indivíduos devem ignorar os resultados e as consequências de seus atos. A tese kantiana defende, de modo diverso, que as consequências não podem ser determinantes para que uma ação tenha valor moral. ${ }^{66}$

Além disso, Hegel critica Kant no que concerne à orientação de sua moralidade, pois os princípios são formais, abstratos e anistóricos. A eticidade de Hegel, ao contrário, "representa o ethos fático dos sistemas sociais, historicamente ativos". ${ }^{67}$

Assim, retorna-se à discussão a respeito da responsabilidade, agora segundo Hegel, o qual entende que ela é "antes de tudo conceito, princípio do espírito e do coração, e se destina a desenvolver-se em objetividade, em efetividade jurídica, ética religiosa e também em realidade científica". ${ }^{8}$ Para Hegel, a ação, "enquanto fim posto na exterioridade, está abandonada a forças externas que podem uni-la com algo totalmente diferente do que ela é por si e eleva-la a estranhas e longínquas consequências. É assim mesmo um direito da vontade fazer-se responsável só do primeiro, porque é o único que estava em seu propósito". Ocorre que é imperioso que há consequências necessárias diretamente ligadas às ações e que nem sempre podem ser previstas. Nessa hipótese, Hegel defende que a ação não pode negar nem depreciar suas consequências. Porém, também é possível que elementos exteriores se agreguem aos resultados da ação, mas não pertençam a ela. ${ }^{69}$

Para que se distinga o que é de responsabilidade do agente e o que não é, Hegel analisa a passagem do propósito para a intenção, ou seja, só o que o indivíduo sabia sobre as consequências pode lhe ser imputado. Hegel distingue que o propósito é individual e a intenção é o propósito universal (o pretendido pelo

\footnotetext{
${ }^{65}$ HEGEL, G. W. F.. Rechtsphilosophie. Frankfurt am Main: Suhrkamp, 1986, § 127.

${ }^{66}$ WEBER, Thadeu. Ética e Filosofia Política: Hegel e o formalismo kantiano. Porto Alegre: EDIPUCRS, 1999, p. 104.

${ }^{67}$ GIMBERNAT, J. Antônio. Las renovadas objeciones hegelianas a la moralidade kantiana (El prisma de la ética discursiva). In Kant después de Kant. Madrid: Tecnos, 1989, p. 601.

${ }^{68}$ HEGEL, G. W. F. Enciclopédia de las Ciencias Filosóficas. México: Juan Pablos Editor, 1974.

${ }^{69}$ HEGEL, G. W. F.. Rechtsphilosophie. Frankfurt am Main: Suhrkamp, 1986.
} 
indivíduo). ${ }^{70}$ Dessa forma, a responsabilidade do agente refere-se a tudo constituído pelos propósitos, intenções e possíveis efeitos casuais decorrentes. Weber atenta para o fato de que enquanto há aqueles que não sabem as consequências de seus atos, há os que as conhecem e mesmo assim os realizam. ${ }^{71}$

O que Hegel quer dizer é que a determinação da validade universal de um princípio não se dá somente pela razão, e a priori, mas pela mediação das vontades. Weber explica: "minha vontade livre tem que se mediar com a vontade livre do outro, a fim de se universalizar". ${ }^{72}$ Hyppolite completa: "O universal, em lugar de ser, como no moralismo kantiano, um em si abstrato, uma transcendência inacessível, se converteu em um momento da ação humana, em ser-para-outro". ${ }^{73}$

A síntese da liberdade substancial, que se dá pelo processo de mediação, superando as vontades mediatas, é a seguinte:

O dever-ser só limita o arbítrio da subjetividade (...). Quando os homens expressam que querem ser livres, em primeiro lugar só querem dizer que querem ser abstratamente livres, e toda determinação e estruturação no Estado aparece como uma limitação para esta liberdade. O dever não é, portanto, limitação da liberdade, mas unicamente de sua abstração, quer dizer, da falta de liberdade. $\mathrm{O}$ dever, ao contrário, implica o alcance da essência, a conquista da liberdade afirmativa. ${ }^{74}$

Desse modo, tem-se que não se pode definir o que deve ser feito e o que deve ser evitado de modo abstrato, pois as circunstâncias e as contingências de cada momento, de cada sociedade, é que vão determinar. Por isso Hegel critica Kant, pois este defende a existência de uma lei moral universal que valha para todos os seres racionais, não se admitindo em exceções em prol de si mesmo. Hegel apresenta seus critérios de moralidade através da coerência e da possibilidade de universalização dos interesses particulares devidamente filtrados pela mediação e pela limitação. ${ }^{75}$

Hegel então define que para se avaliar o ato humano é necessário que sejam consideradas as circunstâncias, os resultados e as consequências, isto é, os desdobramentos das ações dos sujeitos. Com isso, tem-se que para Hegel não

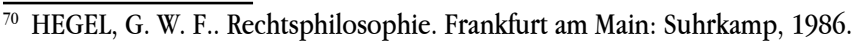

${ }^{71}$ WEBER, Thadeu. Ética e Filosofia Política: Hegel e o formalismo kantiano. Porto Alegre: EDIPUCRS, 1999.

${ }^{72}$ WEBER, Thadeu. Ética e Filosofia Política: Hegel e o formalismo kantiano. Porto Alegre: EDIPUCRS, 1999, p. 110.

${ }^{73}$ HYPOLLITE, J. Introdução à Filosofia da História de Hegel. Lisboa: Edições 70, 1973, p. 449, p. 449.

${ }^{74}$ HEGEL, G. W. F.. Rechtsphilosophie. Frankfurt am Main: Suhrkamp, 1986, § 149.

75 WEBER, Thadeu. Ética e Filosofia Política: Hegel e o formalismo kantiano. Porto Alegre: EDIPUCRS, 1999.
} 
é suficiente apenas que o ato seja bom. É preciso que ele seja verdadeiramente bom, no todo, o que demonstra a necessidade da passagem da moralidade para a eticidade. ${ }^{76}$

Mas o que é eticidade, para Hegel? "Que minha vontade seja posta como adequada ao conceito e com isso superada e guardada (aufgeboben) sua subjetividade". ${ }^{77}$ Assim, dois momentos devem ser observados: a superação da subjetividade (nível em que se situa a moralidade), onde Kant se situou, e a adequação ao conceito (dever-ser), donde decorre o caráter normativo da ação humana.

Weber resume essas máximas de Hegel da seguinte forma:

A mediação é essencial à moralidade, conforme enfatiza na Fenomenologia do Espírito e mostra seu desdobramento na Filosofia do Direito. O conflito que se estabelece entre razão (puro pensar do dever) e sensibilidade (o ser outro) se resolve na "moralidade efetiva" (cf. Fenomenologia do Espirito, § 603). A unidade entre razão (o puro pensar o dever) e sensibilidade (o momento da efetividade) efetua-se através do superar e guardar (Aufbebung) da sensibilidade, dentro do movimento dialético da mediação de vontades livres. ${ }^{78}$

Conforme Valcárcel ${ }^{79}$, "a tríade (Direito, moral, eticidade) decompõe o formalismo e supera a consideração abstrata do dever-ser". A filósofa acrescenta que a determinação do que deve ser exige objetividade, sendo a verdadeira moral social e histórica. Weber aduz que "o ético é a antítese do indeterminado, uma vez que representa a realização da liberdade" e abarca "a existência de fins particulares e a afirmação da liberdade individual, através da mediação das vontades livres dos outros." 80

É no Estado que Hegel vislumbra a conciliação entre as diferenças, entre as vontades individuais e a substancial. Isto porque, segundo ele, o Estado concilia as diferenças, pois temos direitos na medida em que temos deveres e temos deveres na medida em que temos direitos. ${ }^{81}$ É na mediação das diferenças que o indivíduo se liberta dos impulsos meramente naturais e, a partir do dever, através da mediação

\footnotetext{
${ }^{76}$ HEGEL, G. W. F.. Rechtsphilosophie. Frankfurt am Main: Suhrkamp, 1986.

${ }^{77}$ HEGEL, G. W. F.. Rechtsphilosophie. Frankfurt am Main: Suhrkamp, 1986.

${ }^{78}$ WEBER, Thadeu. Ética e Filosofia Política: Hegel e o formalismo kantiano. Porto Alegre: EDIPUCRS, 1999, p. 107.

${ }^{79}$ VALCÁRCEL, Amelia, Hegel y la ética. Sobre la superación de la "mera moral", Barcelona: Editorial Anthropos, 1988, p. 286.

${ }^{80}$ WEBER, Thadeu. Ética e Filosofia Política: Hegel e o formalismo kantiano. Porto Alegre: EDIPUCRS, 1999, p. 109.

${ }^{81}$ HEGEL, G. W. F.. Rechtsphilosophie. Frankfurt am Main: Suhrkamp, 1986.
} 
de vontades (eticidade), ele entra num processo de determinação objetiva e alcança a liberdade substancial. ${ }^{82}$ Hyppolite informa que o universal do moralismo kantiano "se converteu em um momento da ação humana, em ser-para-outro". ${ }^{83}$

Com Hegel, é abandonada a universalidade abstrata para entrar na universalidade concreta. Numa comunidade ética, conforme Hegel, sabemos o que deve ser feito, diferentemente do que decorre do imperativo categórico de Kant, ou seja, que não determina o que deve ser feito. Segundo Weber, o critério de moralidade hegeliano:

[...] passa a ser a possibilidade de universalização a posteriori, isto é, uma universalização resultante da mediação das vontades envolvidas e afetadas. É nela que entram cada vez mais novos conteúdos, passíveis ou não de universalização. $O$ que não for passível de universalização não constitui a substancialidade ética e vai sendo eliminado. ${ }^{84}$

Assim, tem-se que Hegel defende as circunstâncias que determinam o surgimento de novos deveres e, por isso, não podem ser desprezadas quando se trata de valoração moral de um ato. O fato de Kant definir a validade universal do princípio de moralidade impede que seja levada em conta a diferença de conteúdos éticos de cada sociedade, o que, para a tese hegeliana, é inevitável. Na perspectiva de Hegel, o universal se torna individual quando se concretiza, o que ocorre numa comunidade ética, num povo, enquanto a moralidade kantiana permanece no plano formal e abstrato. ${ }^{85}$

Segundo Freitag ${ }^{86}$, "coube a Hegel 'dialetizar' e 'historicizar' o pensamento kantiano". Sem dúvida, foi o que ocorreu, porém, a importância do discurso filosófico de Kant, mesmo sem a crítica de Hegel, seria a mesma. Isto porque, o filósofo prussiano desenvolveu uma filosofia moral aplicável aos mais diversos ramos do pensamento e das ações humanas, sobrevivendo a séculos de mudanças sociais. Por certo a análise de Hegel trouxe mais palpabilidade para a filosofia kantiana, ao estabelecer as consequências das ações humanas como de responsabilidade do agente, assim como a importância da mediação para se possibilitar a universalização do ato moral.

\footnotetext{
${ }_{82}$ WEBER, Thadeu. Ética e Filosofia Política: Hegel e o formalismo kantiano. Porto Alegre: EDIPUCRS, 1999.

${ }^{83}$ HYPOLLITE, J. Introdução à Filosofia da História de Hegel. Lisboa: Edições 70, 1973, p. 449.

${ }^{84}$ WEBER, Thadeu. Ética e Filosofia Política: Hegel e o formalismo kantiano. Porto Alegre: EDIPUCRS, 1999, p. $114-115$.

${ }^{85}$ WEBER, Thadeu. Ética e Filosofia Política: Hegel e o formalismo kantiano. Porto Alegre: EDIPUCRS, 1999.

${ }^{86}$ FREITAG, Barbara. A questão da moralidade: da razão prática de Kant à ética discursiva de Habermas. In Tempo Social; Rev. Social. USP, S. Paulo, VOLUME 1 (1), 1989. Disponível em < http://www.fflch.usp.br/sociologia/ temposocial/site/images/stories/edicoes/v012/a_questao.pdf. > Acesso em 06, ago./2015.
} 
Da mesma forma, a defesa de Hegel no sentido de que o direito, a moral, a família, as instituições e o Estado são os contrapontos ao formalismo kantiano e representam o meio pelo qual a liberdade se concretiza, levando-se em consideração as mais diferentes culturas. Isso se dá, primeiramente na família, depois o convívio social e, por fim, pela atuação do Estado. A partir desses pilares, Hegel ainda estudaria o reconhecimento, assunto para outro ensaio.

Sendo assim, desse embate filosófico surgem as mais variadas interpretações e aplicações, dentre elas a ligação da moral e a ética com a bioética. No tópico seguinte, serão abordadas questões ligadas a este "novo ramo da filosofia moral", estabelecendo-se análise de sua ligação com as filosofias kantiana e hegeliana.

\section{A BIOÉTICA COMO FILOSOFIA MORAL FUNDAMENTADA A PARTIR DAS FILOSOFIAS KANTIANA E HEGELIANA}

A filosofia de Kant e de Hegel serve como base para o estudo do "mais novo ramo da filosofia moral" ${ }^{\text {, }}$, a bioética, no enfoque do tratamento médico-científicotecnológico da vida humana.

Preliminarmente, poderia se argumentar que, se levada em conta a teoria kantiana, não seria possível que se "escolhesse" alguém para morrer, a fim de se salvassem outras vidas (num resgate, por exemplo), assim como não se aceitaria a eutanásia, mesmo que essa negação privasse o indivíduo de sua liberdade de escolha, de sua autonomia e o destinasse a uma vida infeliz e sofrida. Isto porque, Kant defendeu, dentre suas máximas, que um indivíduo somente pode fazer aos outros o que gostaria que estes fizessem para si.

Conforme Andorno ${ }^{88}$, liberdade e responsabilidade são conceitos complementares. Com efeito, em primeiro lugar, cada indivíduo possui direitos e liberdades fundamentais (viés da liberdade) e, em segundo lugar, merece ser protegido contra ameaças graves para a sua dignidade, mesmo que venha a consentir com tais atos (viés da responsabilidade).

\footnotetext{
${ }^{87}$ BARRETTO, Vicente de Paulo. Bioética, Biodireito e Direitos Humanos. In Portal DHNET. Disponível em $<$ http://www.dhnet.org.br/direitos/direitosglobais/paradigmas_textos/v_barreto.html >. Acesso em 07 , ago./2015.

${ }^{88}$ ANDORNO, Roberto. Human dignity and human rights as a common ground for a global bioethics. In Journal of Medicine and Philosophy, 2009. Disponível em < http://www.unesco.org.uy/shs/fileadmin/shs/redbioetica/ dignidad_Andorno.pdf >. Acesso em 07, jun./2016, p. 9
} 
As crescentes mudanças nas áreas da medicina, biologia, genética, tecnologia e outras, propiciam o surgimento de uma gama de relações intersubjetivas e jurídicas que acabam por se defrontar com limites morais, éticos, religiosos e culturais. Assim, o surgimento de novas tecnologias em torno da vida humana pode ser observado a partir de três vieses éticos, sendo a bioética o primeiro deles, a qual é uma referência para os indivíduos, quando trata dos assuntos ligados à ética da vida; num segundo plano, encontram-se os princípios da bioética, os quais podem servir como bases para a tomada de decisões e a elaboração de legislação aplicável a questões desse nível; por fim, o biodireito, o qual deverá se valer de justificativas racionais para que seja válido. ${ }^{89}$

Nesse cenário, é inegável que a bioética vem cada vez mais progredindo como um ramo multidisciplinar, especialmente diante dos avanços da medicina, da tecnologia e do senso de liberdade e autonomia das pessoas. A evolução médicotecnológica se mostra em questões ligadas à fertilização, à investigação biomédica, à escolha de genes, à eutanásia, ao aborto em casos de malformações fetais, aos transplantes entre vivos, etc.. Por outro lado, o fato de as informações acerca dos direitos individuais, dos direitos fundamentais, da autodeterminação do paciente, do fato que os indivíduos possuem autonomia sobre sua vida e liberdade para escolher o melhor tratamento, os medicamentos e as terapias aos quais vão ser submetidos determina que novos casos sejam postos em discussão, fazendo com que o direito, a moral, a ética, a religião e, enfim, a bioética, venham a dialogar para buscarem saídas apropriadas, em favor da vida e da saúde humanas.

Ainda, pode-se trazer à baila o fato de que minorias passaram a exigir mais participação na tomada de decisões, expondo suas questões ligadas à saúde e ao bem-estar, bem como as mulheres em sua luta pela legalização do aborto e os transexuais em seus reclames por reconhecimento e despatologização.

É para superar esses problemas de bioética que o diálogo entre as teorias de Kant e de Hegel se mostra importante, se considerado que aquela ciência se trasmuda em filosofia moral. E, para dar ênfase a esta discussão, apresenta-se o direito como meio de pacificação social, como referido.

$\overline{89}$ BARRETTO, Vicente de Paulo. Bioética, Biodireito e Direitos Humanos. In Portal DHNET. Disponível em $<$ http://www.dhnet.org.br/direitos/direitosglobais/paradigmas_textos/v_barreto.html $>$. Acesso em 07, ago./2015. 
Em passagem elucidativa acerca dessa complementaridade, Andorno ${ }^{90}$ expõe:

Embora a ética e o direito interajam de várias maneiras e possam sobrepor-se significativamente um em relação ao outro, eles permanecem sendo dois sistemas normativos diferentes, pela simples razão de que perseguem objetivos diferentes: a ética reflete o esforço da nossa razão em descobrir se algo é certo ou errado, e tem como objetivo promover o cumprimento das nossas tendências para o bem, pelo menos de acordo com a clássica, ou aristotélica, visão de ética. Em contraste, a lei tem um alcance muito mais estreito que o da ética, porque não procura determinar que a vida humana seja voltada para a moral, mesmo que as normas legais tenham um impacto positivo indireto sobre a atuação moral das pessoas. A finalidade básica de lei é apenas garantir que as relações entre os seres humanos sejam regidas pelo princípio da justiça, ou em outras palavras, que os direitos de cada indivíduo, bem como os interesses comuns da sociedade como um todo, sejam garantidos. Enquanto a questão fundamental da ética é "O que devo fazer para tornar-se uma pessoa melhor?", a questão fundamental da lei é: "Quais as regras que temos de promover uma sociedade pacífica e justa?".

$\mathrm{Na}$ mesma linha, ilustrou Jellinek que é intrincada a relação entre ética e direito, pois a lei possui "a ética mínima" (das etbische minimo), ou seja, apenas as "condições indispensáveis da vida social"11. Por outro lado, a ética abrange um espectro mais amplo do que a lei; e o que é ético não é (e não deve ser) necessariamente ilegal. ${ }^{92}$

Assim, a relação entre o direito e a bioética, não se restringe em aquele avaliar se problemas éticos são resolvidos corretamente ou incorretamente, mas em verificar como eles surgem, de que forma são estruturados e como são gerenciados. E essa preocupação do direito não é relevante para a bioética. ${ }^{93}$

Defende Barretto que "Encontramo-nos, assim, diante do problema nuclear do pensamento social, qual seja, o da convivência de duas ordens normativas - a moral e o direito [...] que mantêm um caráter de complementaridade" ${ }^{94}$

\footnotetext{
${ }^{90}$ ANDORNO, Roberto. Human dignity and human rights as a common ground for a global bioethics. In Journal of Medicine and Philosophy, 2009. Disponível em < http://www.unesco.org.uy/shs/fileadmin/shs/redbioetica/ dignidad_Andorno.pdf $>$. Acesso em 07, jun./2016, p. 2.

${ }^{91}$ JELLINEK, Georg. Die sozialethische Bedeutung von Recht, Unrecht und Strafe. Berlin: Häring, 1908.

92 ANDORNO, op. cit.

${ }^{93}$ EMMERICH, Nathan. A Philosophical Methodology for Sociology in and of Bioethics. In Disponível em < https://www.qub.ac.uk/sites/QUEST/FileStore/Issue6/Filetoupload,146251,en.pdf > . Acesso em 07, jun./2016.

${ }^{94}$ BARRETTO, Vicente de Paulo. Bioética, Biodireito e Direitos Humanos. In Portal DHNET. Disponível em $<$ http://www.dhnet.org.br/direitos/direitosglobais/paradigmas_textos/v_barreto.html $>$. Acesso em 07 , ago./2015.
} 
Bauman ${ }^{95}$ defende que a lei não se esforça para definir ações adequadas e ações inadequadas para solucionar divergências. Por isso, a ética atua para definir a si própria um ideal "of exhaustive and unambiguous definitions" o qual "acts on the assumption that in each life situation one choice can and should be decreed to be good in opposition to numerous bad ones, and so acting in all situations can be rational".

Na mesma linha, Emmerich ${ }^{96}$ aponta que:

A complete ethical, normative, theory is unachievable and we cannot know which is the correct system of morality. The adoption of this perspective on ethics and morality in the social sciences offers an opportunity for an critically engaged, non-absolutist, non-(hard) relativist social science in and of bioethics.

Engelhardt resume que a bioética é "como uma lógica do pluralismo, como um instrumento para a negociação pacífica das instituições morais" ${ }^{\prime 7}$, e, para que isso ocorra, deve haver um princípio moral. A partir daí é que a bioética poderá verificar as "condições racionais para a existência de argumentos, fundadores de princípios, que serão materializados através da ordem jurídica, e visem resguardar a pessoa humana e os seus descendentes". ${ }^{9}$

Nesse ponto, explica Barreto que há "uma tensão permanente entre os valores morais e os cânones éticos encontrados na sociedade pluralista da modernidade", e conclui:

O mais novo ramo da filosofia moral poderá definir, assim, não um código de normas substantivas, que sirva de guia para as políticas públicas de saúde e de pesquisa biológica, mas sim analisar as condições racionais para a existência de argumentos, fundadores de princípios, que serão materializados através da ordem jurídica, e visem resguardar a pessoa humana e os seus descendentes. ${ }^{99}$

Aqui, retorna-se à discussão quanto à responsabilidade pelas ações, em Kant e em Hegel, pois as tecnologias aplicadas às vidas humanas podem desencadear uma

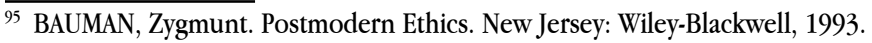

${ }^{96}$ EMMERICH, op. cit.

${ }^{97}$ ENGELHARDT, H. T.. Manuale di Etica. Milano: Il Sagiatore, 1991, p. 19.

${ }^{98}$ BARRETTO, Vicente de Paulo. Bioética, Biodireito e Direitos Humanos. In Portal DHNET. Disponível em $<$ http://www.dhnet.org.br/direitos/direitosglobais/paradigmas_textos/v_barreto.html >. Acesso em 07, ago./2015.

99 BARRETTO, Vicente de Paulo. Bioética, Biodireito e Direitos Humanos. In Portal DHNET. Disponível em $<$ http://www.dhnet.org.br/direitos/direitosglobais/paradigmas_textos/v_barreto.html $>$. Acesso em 07 , ago./2015.
} 
série de consequências, não se sabendo sua magnitude tampouco gravidade, alcance geográfico e temporal. A responsabilidade, no âmbito da bioética, deve preservar a vida, de modo que não pode ser imputada pelo dano causado, mas deve ser mais ampla, talvez fundada num "conceito mais abrangente de responsabilidade moral" ${ }^{100}$

A partir dessa visão de responsabilidade, Hans Jonas propõe a "ética do futuro", a qual

[...] não designa a ética no futuro - uma ética futura concebida na atualidade para os nossos descendentes futuros -, mas sim uma ética da atualidade que se preocupa com o futuro e pretende protege-lo, para os nossos descendentes, das consequências de nossa ação presente. ${ }^{101}$

Sendo assim, a responsabilidade moral, núcleo da ética do futuro, determina-se por aquilo "que se irá fazer; um conceito em virtude do qual eu me sinto responsável, portanto, não em primeiro lugar por meu comportamento e suas consequências, mas da coisa que reivindica o meu agir". ${ }^{102} \mathrm{E}$ assim conclui Jonas:

Nenhuma ética anterior levou em conta as condições globais da vida humana, nem o futuro remoto, mais ainda, a existência mesma da espécie. O fato de que precisamente hoje estão em jogo essas coisas exige, em uma palavra, uma concepção nova de direitos e deveres, algo para o que nenhuma ética, nem metafísica anterior proporciona os princípios e menos ainda uma doutrina já pronta. ${ }^{103}$

No campo da bioética, as implicações das novas tecnologias muitas vezes nem mesmo são conhecidas, sendo de grande importância o estabelecimento de um critério de racionalidade para a tomada de decisões. A crítica de Kant, seu imperativo categórico e sua formulação de liberdade também propiciam que a bioética se fundamente a partir da razão. Mas não somente isso, implica também que venhamos a discutir a respeito das tecnologias, se são necessárias, se podem ser postas em prática, se podem ser universalizadas, se o ser humano será tido como fim em si mesmo.

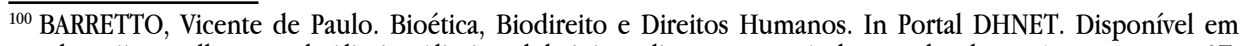
$<$ http://www.dhnet.org.br/direitos/direitosglobais/paradigmas_textos/v_barreto.html $>$. Acesso em 07 , ago./2015.

${ }^{101}$ JONAS, Hans. Le principe responsabilité. Paris: Flammarion, 1998, p. 69.

${ }^{102}$ JONAS, Hans. El principio del resposabilidad: ensayo de una ética para la civilizacion tecnologica. Barcelona: Herder, 1995, p. 132.

${ }^{103}$ JONAS, Hans. El principio del resposabilidad: ensayo de una ética para la civilizacion tecnologica. Barcelona: Herder, 1995 , p. 34.
} 
Em suas relações sociais, o ser humano deve ter a noção de reciprocidade como fundamental para a formação do seu eu social e ético, conforme Hegel. Com isso, ele passa a ter o outro como constituinte do seu eu. Essa alteridade, além da reciprocidade e do reconhecimento, demonstra a preocupação hegeliana para com as consequências das ações humanas. Do mesmo modo, a sua defesa pela mediação, pela consideração da história e da cultura das comunidades possibilita que mais facilmente se verifiquem as contingências do momento e as necessidades, ou não, das tecnologias voltadas à vida humana.

Nessa linha, o que estabelece a filosofia hegeliana, quanto à ética e ao reconhecimento, é que o ser humano deve reconhecer o outro como tal, para ser reconhecido. A reciprocidade é fortemente marcada nos escritos de Hegel, de modo que vale sua abordagem para as questões de bioética. $\mathrm{O}$ agir humano, para benefício próprio, através da utilização de outro ser humano como instrumento não pode ser válido do ponto de vista moral, pois, para Kant, essa conduta não pode ser universalizada e, para Hegel, a responsabilidade para com as consequências dessa ação pertence ao agente e o se reconheço o outro como mero meio, não posso me reconhecer como um fim em si mesmo, um ser detentor de dignidade.

Para ilustrar, podemos enumerar alguns pontos abordados pela bioética, como a engenharia genética, em seu ponto negativo, faria com que o ser humano se resumisse aos genes, perdendo sua autonomia. Ao perdê-la, como poderá o imperativo categórico, via sua quarta fórmula ${ }^{104}$, ser considerado? O determinismo genético viria a justificar as ações das pessoas, tornando-as meros reflexos da natureza, da combinação de genes. De que modo estaria a salvo a liberdade, objeto de estudo das teorias dos dois filósofos? As modificações genéticas podem salvar o planeta da fome, através de novos produtos alimentícios, mais resistentes às pragas, ou serem utilizados para o lucro das empresas que os produzem? Na perspectiva de Kant, podemos universalizar a derrocada da fome. Pela crítica de Hegel, temos que o lucro não é imoral, assim, como ser impedido?

Por isso, a necessidade de se estabelecer fundamento racional à bioética suscita as formulações dos imperativos categóricos de Kant, bem como a moralidade e a eticidade em Hegel, preocupadas com a concretização da ideia de liberdade nas instituições sociais e com as repercussões das ações humanas.

Assim, se para Kant, as leis jurídicas e éticas são leis morais, que expressam um dever-ser em contraposição às leis da natureza, Hegel concebe igualmente 0

104 "Age de tal maneira que a vontade pela sua máxima se possa considerar a si mesma, ao mesmo tempo, como legisladora universal". 
direito e a moral como esferas de concretização da liberdade. Em "Preleções sobre a história da Filosofia", o autor consagra essa base teórica comum inspirada pela herança kantiana. As esferas do espírito objetivo são concebidas como "ser-aí da vontade livre". Hegel reconhece a virtude kantiana de teorizar que a vontade livre não deve ser concebida como puro arbítrio. Outrossim, endossa a tese kantiana que considera a vontade como a faculdade suprema de desejar com base em fins universais. Nesse ponto, Hegel concebe o concreto como a unidade entre a vontade particular e a vontade universal. Essa articulação entre a vontade universal e a particular que permite um "sistema do espírito" que se realiza.

Ambos os autores pressupõem o resultado da diferenciação decorrente dos elementos subjetivos e objetivo da legislação. Em Kant, a obrigação jurídica pode converter-se em obrigação de virtude quando, em face da inexistência de coerção, a conduta é praticada por obrigação. Hegel incorpora posicionamento similar. Nas suas ponderações, a obrigação da vontade subjetiva é atuar em conformidade com o sistema jurídico e zelar pelo bem-estar individual e universal. A intenção moral é insuscetível de legitimar uma ação ilegal posto que permanece inexistente o aspecto necessário para a construção do ethos.

A autonomia de Kant, o respeito fundamental pela pessoa como fim em si, é encaixada à bioética, a qual se expressa como uma consciência solidária, contrária à manipulação da pessoa humana, como defende Portocarrero. ${ }^{105} \mathrm{~A}$ mesma autora critica essa autonomia kantiana, concluindo por sua ineficiência quando se trata da situação dos doentes, ou seja, mesmo protegendo-os, ela os sacrifica em seus interesses e, por isso, "é hoje denunciada no seu estatuto de pilar da filosofia moral porque pressupõe uma imagem demasiado rígida do agente moral". Igualmente, porque "obriga o juízo e a ação moral a uma imparcialidade que não toma em linha de conta as contingências e as singularidades das nossas relações concretas com os outros". Conclui Portocarrero que, "por outras palavras, ela [a autonomia] esquece o trágico da ação, a necessidade da deliberação circunstanciada e do conselho". ${ }^{106}$

Talvez essa "deliberação circunstanciada" possa ocorrer através da mediação e da consideração das comunidades éticas, da história e da cultura de cada povo,

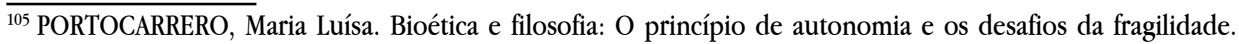
In Revista Filosófica de Coimbra, 44, 2013. Disponível em <http://www.uc.pt/fluc/dfci/public_/publicacoes/ bioetica_e_filosofia >. Acesso em 06, ago./2015.

${ }^{106}$ PORTOCARRERO, Maria Luísa. Bioética e filosofia: O princípio de autonomia e os desafios da fragilidade. In Revista Filosófica de Coimbra, 44, 2013. Disponível em <http://www.uc.pt/fluc/dfci/public_/publicacoes/ bioetica_e_filosofia >. Acesso em 06, ago./2015.
} 
como propõe Hegel. A bioética pode nos fazer pensar mais a respeito de que essas expressões diversas dos seres humanos são muito importantes para exprimir o "compromisso entre o desejo de liberdade de consciências singulares e situações caraterizadas eticamente", para o propósito maior que é o bem estar do ser humano.

A bioética, portanto, como um novo ramo da filosofia moral, poderá responder à sociedade contemporânea, uma de suas principais indagações, no sentido de que é possível se universalizar direitos morais "fundados numa concepção ética do Direito e do Estado, vale dizer, na construção de uma ordem normativa construída através do diálogo racional entre pessoas livres". ${ }^{107}$

Com isso, a bioética possibilitará que o ser humano desenvolva critérios morais e éticos para a tomada de decisões no que toca à vida, em seus mais diversos reclames, sejam de liberdade, de autonomia, de reciprocidade.

\section{CONSIDERAÇÕES FINAIS}

Poder querer que uma máxima da ação humana se transforme em lei universal é o critério moral de Kant. Hegel apontou a insuficiência deste critério, pois seria indeterminado, ou seja, estritamente formal. A ética de Kant, portanto, é de intenções, do cumprimento do dever pelo dever. Hegel, por outro lado, entendeu que a ética deve ser pautada pelas consequências da ação humana (responsável).

Pela análise da moralidade de Kant a partir do imperativo categórico, suas fórmulas e possibilidade, passando pela abordagem da liberdade como condição da moralidade e da responsabilidade como tema de filosofia, foi possível observar que a crítica de Hegel e seus aportes à moralidade e à ética ensejam debate profundo para se fundamentar a bioética como filosofia moral. Isto porque, através desta abordagem, a bioética possibilitará que o ser humano desenvolva critérios morais e éticos para a tomada de decisões no que toca à sua vida, em seus mais diversos reclames, sejam de liberdade, de autonomia, de reciprocidade, sempre considerando o respeito às vidas dos demais, em estrito cumprimento de sua responsabilidade, presente tanto em Kant, como em Hegel e que acaba por replicar e ressurgir na bioética.

Constatou-se que Hegel criticou o formalismo kantiano porque entendeu que não deve haver separação entre forma e conteúdo, na determinação da lei moral

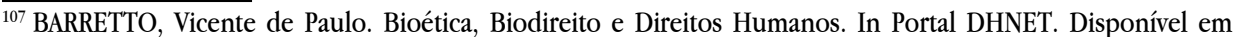
$<$ http://www.dhnet.org.br/direitos/direitosglobais/paradigmas_textos/v_barreto.html $>$. Acesso em 07 , ago./2015.
} 
e na qualificação de um ato como tal. O filósofo perpassou seu pensamento pelas instituições sociais, pela mediação de liberdades, vindo a propor uma eticidade baseada no caráter social e histórico do dever-ser, decompondo o formalismo kantiano.

Assim, a complementaridade entre Kant e Hegel é evidente, pois a determinação dos princípios da moralidade, sua aplicação e a avaliação do agir humano não se explicam somente através da teoria kantiana, ou da hegeliana. Elas se completam quando a filosofia de Kant definiu a ética das intenções (dever pelo dever) e Hegel a aperfeiçoou com os meios, as consequências e os resultados das ações humanas, através das instituições sociais (ética de responsabilidade).

A bioética, como novo ramo da filosofia moral, ao aproveitar-se das filosofias de Kant e de Hegel, poderá trazer à contemporaneidade as discussões envolvendo a vida humana, diante das novas tecnologias, dos avanços da medicina, das novas discussões acerca da sexualidade, do aborto, do início da vida, da eutanásia, entre outros temas relevantes a afetos à bioética.

Com isso, poderá se demonstrar que é possível a existência de direitos morais universais ${ }^{108}$, sem que se tenha de abandonar ou focar as ações humanas somente as (nas) intenções ou as (nas) consequências, mas pela união das mesmas, para se obter o fim maior que é a proteção da vida humana, em todas as suas formas.

\section{REFERÊNCIAS}

BARRETTO, Vicente de Paulo; BRAGATO, Fernanda Frizzo. Leituras de Filosofia do Direito. Curitiba: Juruá, 2013.

BARRETTO, Vicente de Paulo. Bioética, Biodireito e Direitos Humanos. Portal DHNET. Disponível em <http:/www.dhnet.org.br/direitos/direitosglobais/ paradigmas_textos/v_barreto.html>.Acesso em 07, ago./2015.

CAFFARENA, E. Gomez. Razón Práctica, Razón Utópica. Agora Papelos de Filosofía. Santiago de Compostela: Inprensa Universitaria, 1988, p. 177-192.

\footnotetext{
${ }^{108}$ Sempre se considerando que não é possível a imposição de valores a diferentes sociedades sem a devida investigação científica prévia, caso contrário, poderia se afetar negativamente a bioética, como ética humanística que é.
} 
CHAUÍ, Marilena de Souza. Convite à Filosofia. São Paulo, SP: Ática, 2000.

COMTE-SPONVILLE, A. Bom dia, angústia! São Paulo: Martins Fontes, 1997.

FREITAG, Barbara. A questão da moralidade: da razão prática de Kant à ética discursiva de Habermas. Tempo Social; Rev. Social. USP, S. Paulo, VOLUME 1 (1), 1989. Disponível em < http://www.fflch.usp.br/sociologia/temposocial/site/images/ stories/edicoes/v012/a_questao.pdf. $>$ Acesso em 06, ago./2015.

ENGELHARDT, H. T. Manuale di Etica. Milano: Il Sagiatore, 1991.

GIMBERNAT, J. Antônio. Las renovadas objeciones hegelianas a la moralidade kantiana (El prisma de la ética discursiva). In: KANT después de Kant. Madrid: Tecnos, 1989.

HEGEL, G. W. F. Enciclopédia de las Ciencias Filosóficas. México: Juan Pablos Editor, 1974.

HEGEL, G. W. F. Rechtsphilosophie. Frankfurt am Main: Suhrkamp, 1986.

HEGEL, G. W. F. Phänomenologie des Geistes. Frankfurt am Main: Suhrkamp, 1986.

HEGEL, G. W. F. Sobre las maneras de tratar cientificamente el derecho natural. Madrid: Aguilar, 1979.

HYPOLLITE, J. Introdução à Filosofia da História de Hegel. Lisboa: Edições 70, 1973.

JONAS, Hans. El principio del resposabilidad: ensayo de una ética para la civilizacion tecnologica. Barcelona: Herder, 1995.

JONAS, Hans. Le principe responsabilité. Paris: Flammarion, 1998.

KANT, Immanuel. Fundamentação da metafísica dos costumes. Tradução de Paulo Quintela. São Paulo: Abril, 1980.

KANT, Immanuel. Grundlegung zur Metaphysik der Sitten. Tradução de Paulo Quintela, Lisboa: Edições 70, 1986. 
KANT, Immanuel. Kritik der praktischen Vernunft. Crítica da Razão Prática. Tradução de A. Morão. Lisboa: Edições 70, 1994.

KANT, Immanuel. Kritik der reinen Vernunft. Crítica da Razão Pura. Tradução de M. P. dos Santos e A. F. Morujão. Lisboa: Fundação Calouste Gulbenkian, 1994.

KANT, Crítica da Razão Pura. 5 ed. Tradução: Manuela Pinto dos Santos e Alexandre Fradique Morujão. Lisboa: Fundação Calouste Gulbenkian, 2001.

KANT, Fundamentação da metafísica dos costumes e outros escritos. Tradução: Leopoldo Holzbach. São Paulo, SP: Martin Claret, 2005.

MENESES, Ramiro Délio Borges de; REIS, Ana M. Machado Gonçalves Reis. Responsabilidade em Kant e em Lévinas: entre os conceitos e os fundamentos. Ágora Filosófica. Ano 9, n. 2, jul./dez./2009, p. 103-126. Disponível em <http:// www.saavedrafajardo.org/Archivos/59.pdf> . Acesso em 07, ago./2015.

MONDIN, Battista. Curso de Filosofia. Tradução: Benoni Lemos. v. II. São Paulo: Paullus, 2007. 3 vol.

PATON, H. J. The categorial imperative: a study in Kant's moral philosophy. Philadelphia: University of Pennsylvania Press, 1971.

PORTOCARRERO, Maria Luísa. Bioética e filosofia: O princípio de autonomia e os desafios da fragilidade. Revista Filosófica de Coimbra, v. 44, 2013. Disponível em $<$ http://www.uc.pt/fluc/dfci/public_/publicacoes/bioetica_e_filosofia $>$. Acesso em 06 , ago./2015.

TUGENDHAT, Ernst. Lições sobre ética. Trad. Ernildo Stein e Ronai Rocha. Petrópolis: Vozes, 1997.

VALCÁRCEL, Amelia. Hegel y la ética. Sobre la superación de la "mera moral", Barcelona: Editorial Anthropos, 1988.

WEBER, Thadeu. Ética e Filosofia Política: Hegel e o formalismo kantiano. Porto Alegre: EDIPUCRS, 1999. 